\title{
Photosynthesis patterns in Chesapeake Bay phytoplankton: short- and long-term responses of P-I curve parameters to light
}

\author{
Lawrence W. Harding, Jr. ${ }^{1}$, Blanche W. Meeson ${ }^{1}$ \& Thomas R. Fisher, Jr. ${ }^{2}$ \\ ${ }^{1}$ Chesapeake Bay Institute, The Johns Hopkins University, Shade Side, Maryland 20764, USA \\ ${ }^{2}$ Horn Point Laboratories, University of Maryland, Cambridge, Maryland 21613, USA
}

\begin{abstract}
Pigment concentrations and photosynthetic rates of phytoplankton in Chesapeake Bay were examined to determine short- and long-term responses to light. Samples were collected horizontally along a turbidity gradient and vertically relative to the depths of the pycnocline and photic zone. This approach provided phytoplankton assemblages that were exposed to light differing in both intensity and time-scale of change. Photosynthesis-irradiance (P-I) curves and the parameters $\alpha^{B}$ and $\mathrm{P}_{\mathrm{m}}{ }^{\mathrm{B}}$ were assayed at light intensities and wavelength bands that occur in situ. Short-term (minutes to hours) changes in light elicited responses in the distribution of $\alpha^{B}$ and $P_{m}{ }^{B}$ coordinate pairs along a single line. Long-term (days to weeks) differences in light elicited a change in the relation of $\alpha^{B}$ to $P_{m}^{B}$ manifested as a shifted slope of the linear correlation of these parameters. Photosynthetic efficiencies were similar in light sources of narrow ('blue-green' or 'orange') and broad spectra ('white'), indicating the successful harvesting of light of these spectral qualities by photosynthetic pigments in resident phytoplankton. This similarity in photosynthetic efficiency represents a long-term response that may depend on floral composition and differences in pigmentation. Concentrations and ratios of photosynthetic pigments revealed seasonal and spatial differences in floral composition of phytoplankton in Chesapeake Bay. The presence of chrysophytes, diatoms, and dinoflagellates was indicated by low molar ratios of $\mathrm{chl} a$ and $c$ during spring and summer, while the abundance of cyanobacteria (bluegreen algae) was documented by high $a: b$ and $a: c$ ratios in autumn. These findings have implications for the use of P-I curve parameters in diagnosing photoadaptive responses by phytoplankton and for the seasonal abundance of cyanobacteria possibly associated with eutrophication of Chesapeake Bay.
\end{abstract}

\section{INTRODUCTION}

The response of phytoplankton to light has been a topic of much research in the last few years. Little attempt has been made, however, to integrate conceptually the responses to light quality (i.e. spectral distribution) and total photon flux for natural assemblages, despite the fact that a need to do so was recognized nearly 50 yr ago (Gabrielsen \& Steemann Nielsen 1938, Baatz 1941). In estuarine environments, vertical and horizontal gradients in both the total amount of light available, and in the wavelength distribution of that light, are apparent and potentially significant (cf. Jerlov 1976, Kirk 1976, 1979, 1983, Champ et al. 1980, Larkum \& Barrett 1983). Sediment load, dissolved substances, and phytoplankton biomass are elevated in estuaries, producing shallow photic zones and a vertical spectral distribution that is significantly different from that of coastal and oceanic waters. In Chesapeake Bay, for example, not only does turbidity restrict the amount of light available to phytoplankton in photic zones of only several meters, but an 'orange shift' occurs wherein light of wavelengths from 515 to $600 \mathrm{~nm}$ penetrates relatively deeper than does light of other wavelength bands (Champ et al. 1980). This situation is distinct from oceanic regions where the photic zone can exceed $100 \mathrm{~m}$ in depth, 'bluegreen' light penetrates deepest, and longer 'orange' to 'red' wavelengths are rapidly attenuated (Jerlov 1976, Kirk 1983).

Photosynthesis of estuarine phytoplankton is potentially influenced by both the reduced total amount of light available in the water column and by shifts in spectral quality. While adaptations to light of different intensities are well-described for phytoplankton (reviews: Falkowski 1980, Prezelin 1981), cells of vari- 
ous taxonomic groups possess distinct groups of photosynthetic pigments with specific absorption properties that may also influence their ability to use light of different spectral qualities (Wallen \& Geen 1971a, b, Qasim et al. 1972, Jeffrey \& Vesk 1977, Vesk \& Jeffrey 1977, Jeffrey 1980, Meeson \& Faust 1985). As a consequence of this diversity in pigment content, phytoplankton can, to some extent, match absorption of light to the available spectrum of photic energy. Achieving a match of availability and absorption may significantly enhance the rate of photosynthetic carbon assimilation.

In Chesapeake Bay, phytoplankton distributions are greatly affected by a seasonal transport of cells below the pycnocline, associated with 2-layered circulation and other physical processes. Annual bloom and decline sequences for certain species of diatoms and dinoflagellates that undergo such a transport are prominent features in the estuary (cf. Tyler \& Seliger 1978, 1981, Seliger et al. 1981). For example, the dinoflagellate Prorocentrum mariae-lebouriae experiences a lengthy, subpycnocline transport in saline, northwardflowing waters during winter and early spring. Concentrations of this species can reach $>40,000$ cells $\mathrm{ml}^{-1}$ in environments with 'low light' $(<<1 \%$ surface irradiance $I_{0}$ ) of narrow spectral distribution. Thus, hydrographic regulation of the distribution of algal cells in Chesapeake Bay provides a combination of light cues that can impact survival of phytoplankton during transport and influence seasonal patterns of bloom development.

We examined the photosynthesis-irradiance (P-I) relation for natural phytoplankton assemblages in Chesapeake Bay. The hypothesis we tested was that phytoplankton show photosynthetic responses to different time-scales of exposure to low light, and that these responses are manifested in the magnitudes and distributions of values for light-limited $\left(\alpha^{\mathrm{B}}\right)$ and lightsaturated $\left(\mathrm{P}_{\mathrm{m}}{ }^{\mathrm{B}}\right)$ photosynthesis. To that end, our main experimental goal was to distinguish short-term and long-term responses to the quantity and quality of light available to estuarine phytoplankton along horizontal and vertical gradients in photic conditions. We mimicked in situ conditions using light sources that provided 3 distinct spectra over a range of intensities. Concentrations and molar ratios of photosynthetic pigments were measured to assess variations in phytoplankton biomass and in accessory light-harvesting pigments as indicators of floral composition and light adaptation.

\section{MATERIALS AND METHODS}

Three cruises were conducted aboard the R/V Cape Hatteras in March, July, and October, 1982, in
Chesapeake Bay (Fig. 1). On each cruise, designated CB-1 to CB-3, an initial transect was made along a north-south axis in the deep channel of the estuary, covering the entire salinity gradient. Measurements of salinity $(\mathrm{S})$, temperature $(\mathrm{T})$, oxygen $\left(\mathrm{O}_{2}\right)$, chlorophyll a (chl), light attenuation $\left(\mathrm{k}_{\mathrm{t}}\right)$, and dissolved inorganic nutrients $\left(\mathrm{NO}_{3}{ }^{-}, \mathrm{NO}_{2}{ }^{-}, \mathrm{NH}_{4}{ }^{+}, \mathrm{PO}_{4}{ }^{3-}, \mathrm{SiO}_{4}\right)$ were made while underway and with a series of vertical hydrocasts spaced at $20 \mathrm{n}$ mile intervals. Distributions of these properties were used to select stations for studies of photosynthesis. The methods used on transects and

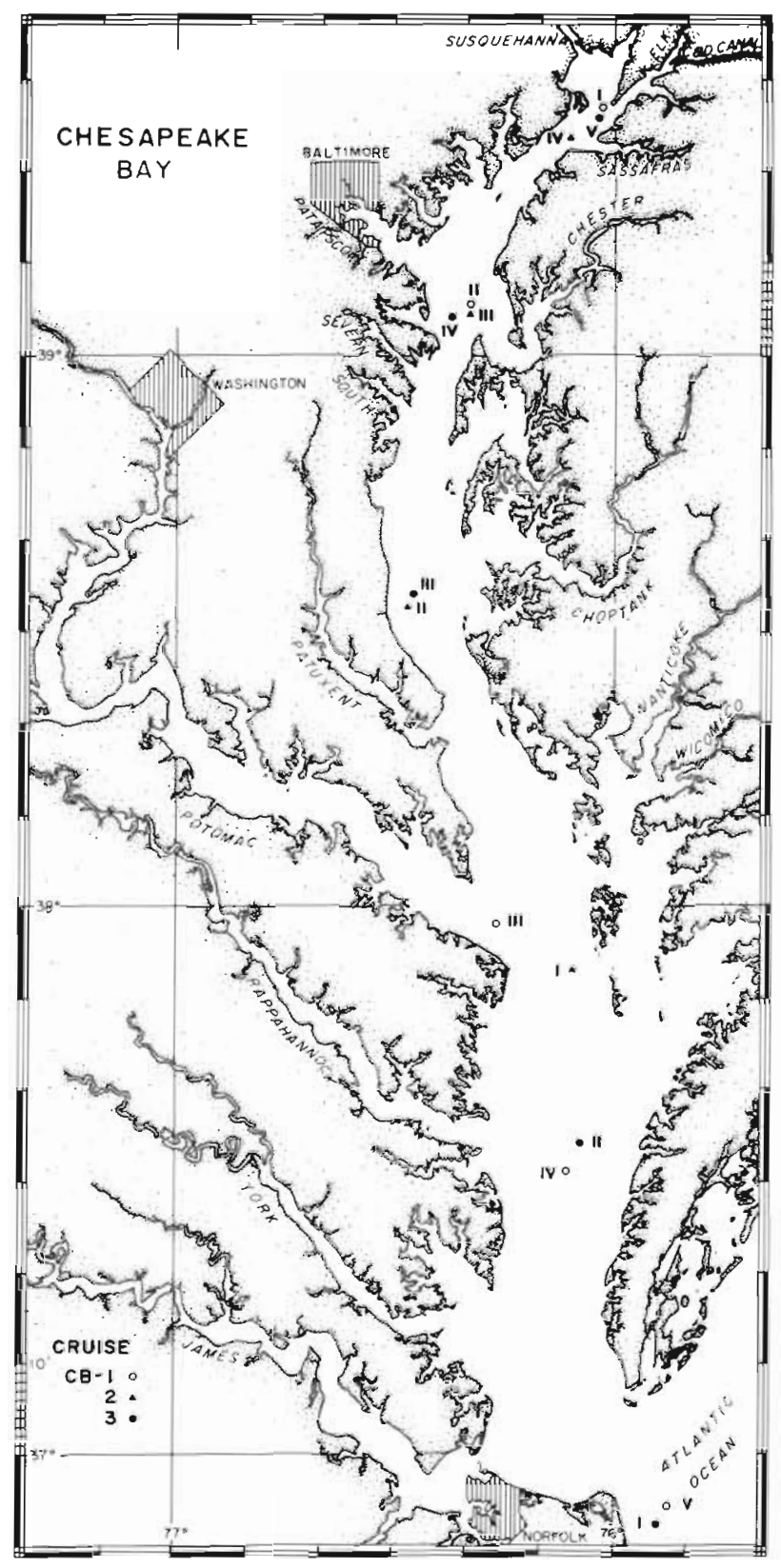

Fig. 1. Chesapeake Bay study area showing locations of stations for 3 cruises in 1982 
detailed data on property distributions will be presented elsewhere (Fisher et al. unpubl.).

On the cruises we occupied 4 or 5 stations for $24 \mathrm{~h}$ each and made measurements of phytoplankton photosynthetic rates. Samples were collected from dawn to dusk at approximately 3 to $4 \mathrm{~h}$ intervals. At stations with well-mixed water columns, a single sample was taken from a depth of $1 \mathrm{~m}$ using a Niskin bottle or a diaphragm pump. Stations with stratified water columns were sampled in the surface mixed layer $(1 \mathrm{~m})$, in the pycnocline $\left(Z_{m}\right)$, and at the base of the photic zone $\left(Z_{p}\right)$ (Table 1). Some variation in the depth of these features, particularly the surface mixed layer, occurred at each station due to tides.

Ambient irradiance at the surface $\left(\mathrm{I}_{0}\right)$ was measured continuously with a Licor model 550 integrating quantum meter with a model $190 \mathrm{~S}$ probe. The total light attenuation coefficient, $k_{t}$, was calculated from vertical profiles of irradiance made with a Licor model 188B quantum meter equipped with a $192 \mathrm{~S}$ sensor. Both meters measure photosynthetically active radiation (PAR) in the visible wavelengths from 400 to $700 \mathrm{~nm}$. Depth of the photic zone $\left(Z_{p}\right)$ was estimated as the depth to which $1 \%$ surface irradiance penetrated.

Photosynthesis was measured in $125 \mathrm{ml}$ glass-stoppered bottles with $2 \mu \mathrm{Ci}{ }^{14} \mathrm{C}$-sodium bicarbonate (ICN Pharmaceutical, Inc.). The bottles were incubated for 2 $\mathrm{h}$ in artificial light incubators using the light sources described below. Seawater from the ship's pumps maintained surface temperature in the incubators. Following incubation, samples were filtered onto $25 \mathrm{~mm}$ Gelman A/E glass fiber filters, rinsed with filtered water from the Bay, and gently washed with filtered, slightly acidified $(0.01 \mathrm{~N} \mathrm{HCl})$ station water to remove inorganic label. Filters were placed in liquid scintillation (LS) minivials with $4 \mathrm{ml}$ Aquasol (New England
Nuclear, Inc.), and counted on a Packard model 3320 LS Counter. Total $\mathrm{CO}_{2}$ was measured by a gas-stripping technique on a Beckman model 864 infrared analyzer.

Published data on wavelength-specific light extinction coefficients in Chesapeake Bay were used to select the light sources for our incubations (Fig. 2; Champ et al. 1980). We used combinations of specific lamps and colored filters to approximate the in situ photic environment. Three distinct qualities of light were used (Fig. 3). 'White' light was supplied to the shallowest $(1 \mathrm{~m})$ samples by combining very high out-

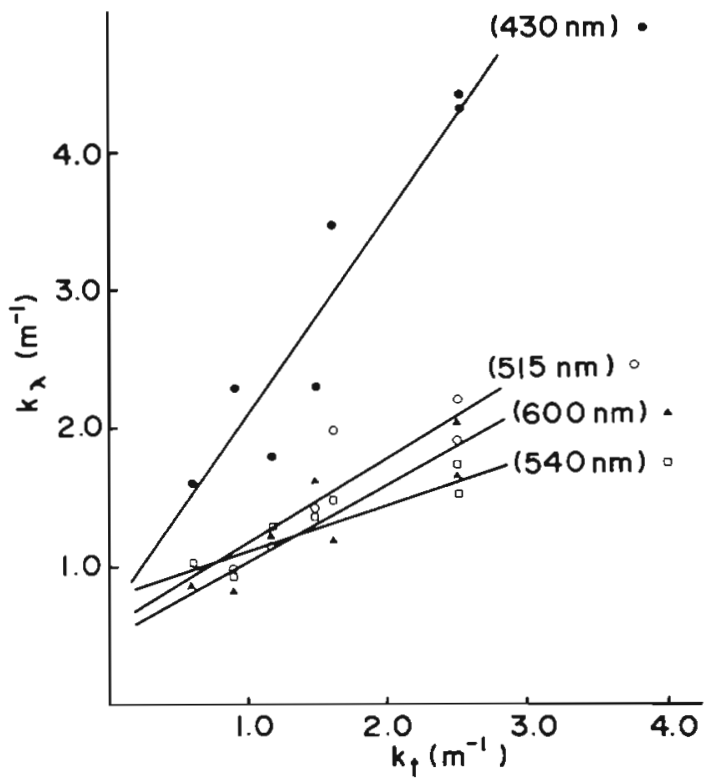

Fig. 2. Wavelength-specific extinction coefficients, $k_{\lambda}$, for 4 wavelength bands from 430 to $600 \mathrm{~nm}$, vs the total light extinction coefficient, $k_{i}$, demonstrating enhanced penetration of 'green' to 'orange' light (540 to $600 \mathrm{~nm}$ ) in Chesapeake Bay (data adapted from Champ et al. 1980)

Table 1. Summary of station locations by coordinates, geographic location, and feațure

\begin{tabular}{|lrllll}
\hline \multirow{2}{*}{ Cruise } & Station & \multicolumn{2}{c}{ Coordinates } & Location & \multirow{2}{*}{ Feature } \\
& & N Latitude & W Longitude & & \\
\hline CB-1 & I & $39^{\circ} 26.8^{\prime}$ & $76^{\circ} 01.7^{\prime}$ & Turkey Point & Freshwater/turbidity maximum \\
Mar 82 & II & $39^{\circ} 06.5^{\prime}$ & $76^{\circ} 19.6^{\prime}$ & Chester R. Mouth & Upper estuary \\
& III & $37^{\circ} 57.2^{\prime}$ & $76^{\circ} 13.8^{\prime}$ & Potomac R. Mouth & Mid-estuary \\
& IV & $37^{\circ} 31.0^{\prime}$ & $76^{\circ} 06.3^{\prime}$ & Rappahannock R. Mouth & Chlorophyll/productivity maximum \\
& V & $36^{\circ} 55.3^{\prime}$ & $76^{\circ} 52.8^{\prime}$ & Cape Henry & Continental shelf \\
CB-2 & I & $37^{\circ} 53.8^{\prime}$ & $76^{\circ} 05.5^{\prime}$ & Potomac R. Mouth & Mid-estuary \\
Jul 82 & II & $38^{\circ} 33.0^{\prime}$ & $76^{\circ} 29.0^{\prime}$ & Choptank R. Mouth & Chlorophyll/productivity maximum \\
& III & $39^{\circ} 05.8^{\prime}$ & $76^{\circ} 19.0^{\prime}$ & Chester R. Mouth & Upper estuary \\
& IV & $39^{\circ} 23.0^{\prime}$ & $76^{\circ} 07.1^{\prime}$ & Turkey Point & Turbidity maximum \\
CB-3 & I & $36^{\circ} 52.0^{\prime}$ & $75^{\circ} 54.0^{\prime}$ & Cape Henry & Continental shelf \\
Oct 82 & II & $37^{\circ} 34.1^{\prime}$ & $76^{\circ} 06.7^{\prime}$ & Rappahannock R. Mouth & Lower estuary \\
& III & $38^{\circ} 33.7^{\prime}$ & $76^{\circ} 27.6^{\prime}$ & Choptank R. Mouth & Productivity maximum \\
& IV & $39^{\circ} 03.7^{\prime}$ & $76^{\circ} 22.3^{\prime}$ & Chester R. Mouth & Productivity maximum \\
& V & $39^{\circ} 25.7^{\prime}$ & $76^{\circ} 01.6^{\prime}$ & Turkey Point & Turbidity/chlorophyll maximum \\
\hline
\end{tabular}




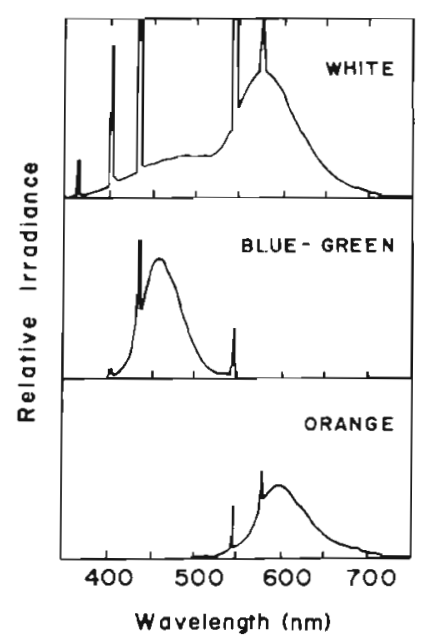

Fig. 3. Spectral distributions of light provided to phytoplankton samples during incubations for determining P-I curve parameters

put (VHO) cool white fluorescent lamps (GE F48T12 $\mathrm{CW} / 1500 \mathrm{ma}$ ) with neutral density screens to give a range of irradiances. Samples from intermediate depths were exposed to 'blue-green' light from blue VHO Sylvania lamps (FY48T12 \#246/1500ma) with Roscolene blue-green filter \#858 (Kliegel Bros. Universal Stage Lighting Co., Long Island, New York). Deepest samples were incubated in 'orange' light from VHO warm-white fluorescent lamps (GE F48T12 WW/ $1500 \mathrm{ma}$ ) with Roscolene medium orange filter \#818. The plastic filters served to narrow the spectral bands provided by the fluorescent lamps and to reduce the irradiance from mercury bands. A quantum spectral radiometer with a resolution of $2 \mathrm{~nm}$ (C-3 Spectral Scanning System, Gamma Scientific, San Diego, California) was used to measure the light spectra and intensities supplied by the lamp and filter combinations.

Parameters of the P-I relation were determined from ${ }^{14} \mathrm{C}$ data using the curve fitting method of Bard (1974) to estimate $\alpha^{\mathrm{B}}$ and $\mathrm{P}_{\mathrm{m}}{ }^{\mathrm{B}}$, as applied by Platt et al. (1980) and Gallegos \& Platt (1981). The program for fitting P-I curves to a hyperbolic tangent function (see Jassby \& Platt 1976) was kindly provided by T. Platt and run on a VAX 750 (Digital Equipment Corporation, Inc.). Statistical analyses of P-I curve parameters were 2-way analysis of variance (ANOVA) for $\alpha^{B}$ and Student's ttest for $\mathrm{P}_{\mathrm{m}}{ }^{\mathrm{B}}$.

Samples were collected for analysis of photosynthetic pigment concentrations at the beginning of each incubation. For initial surveys of phytoplankton distributions, a small volume of sample (10 to $25 \mathrm{ml}$ ) was filtered onto a $25 \mathrm{~mm}$ A/E glass fiber filter for fluoromethric chl a analysis (Strickland \& Parsons 1972). Samples for quantifying other pigments (200 to $500 \mathrm{ml}$ ) were filtered onto a $47 \mathrm{~mm}$ diameter, $0.4 \mu \mathrm{m}$ pore size Nuclepore filter. Pigments were extracted in ice-cold $90 \%$ acetone using a teflon-tipped tissue grinder. Concentrations of chlorophylls $a, b$, and $c$ $\left(c_{1}+c_{2}\right)$, and total carotenoids were determined on a Beckman DK-2 ratio-recording spectrophotometer using the methods and equations of Jeffrey (1968, 1981), and Jeffrey \& Humphrey (1975). Pigment concentrations are expressed as molar quantities using the following molecular weights: chl $a=893, \mathrm{chl} b=907$, chl $c=610$; carotenoids $=550$. For comparison, $1 \mu \mathrm{g}$ chl $a$ is approximately equivalent to $0.9 \mathrm{nmol} \mathrm{chl} a$.

\section{RESULTS}

The 3 cruises on Chesapeake Bay extended over the horizontal salinity gradient from the estuarine plume on the continental shelf to the freshwater end of the estuary at the Susquehanna River. Along this cruise track, phytoplankton were collected from relatively clear water in typical coastal conditions to highly turbid water in the upper estuary. Light attenuation and other hydrographic properties of the sampling stations are given in Table 2. Distributions of suspended particulate material and chlorophyll a concentrations along the salinity gradient (Fig. 4) were used to locate the turbidity and chlorophyll maxima and to select stations. In general, there was a turbidity maximum at a salinity of $<5$ to $10 \%$, and a chlorophyll a maximum at 5 to $20 \%$ that occurred seaward of the turbidity maximum and coincided with the peak in areal production (Table 1). The chl a maxima occurred at Sta. IV on Cruise CB-1, Sta. II and III on CB-2, and Sta. IV on CB-3. Additional data on distributions of properties will be presented elsewhere (Fisher et al. unpubl., Harding et al. unpubl.)

Strong spatial and temporal differences in the phytoplankton flora of Chesapeake Bay were indicated by concentrations and ratios of chlorophylls and accessory pigments (Table 3 ). Chl a concentrations typically varied by a factor of 2 to 8 among stations on each cruise. Phytoplankton near the chl $a$ and productivity maxima in the region seaward of the turbidity maximum usually had pigment concentrations and ratios indicating a predominance of organisms containing chl $a$ and $c$ during early spring (CB-1) and summer (CB-2) (Fig. 5 , Table 3). In autumn (CB-3), chl a and productivity maxima occurred in the upper estuary, while chl $b$ and $c$ concentrations were very low compared to values for chl $a$. This resulted in very high molar ratios for chlorophylls $a: b$ and $a: c$.

Phytoplankton in Chesapeake Bay showed both seasonal and spatial variability in $\alpha^{\mathrm{B}}, \mathrm{P}_{\mathrm{m}}{ }^{\mathrm{B}}$, and the light saturation parameter, $I_{k}$ (Table 4). The statistical significance of differences in P-I curves is summarized in Table 5. The most apparent differences in $\alpha^{B}$ values were for samples from different depths, and occurred on Cruise CB-2 when samples from mid-depth showed significantly higher initial slopes of P-I curves $\left(\alpha^{B}\right)$ than 
Fig. 4. Distributions of suspended particulate material and chlorophyll a vs salinity for the 3 Chesapeake Bay cruises. Abbreviations of locations: TP, Turkey Point; BB, Bay Bridge; PR, Potomac River; CHn, Cap Henry

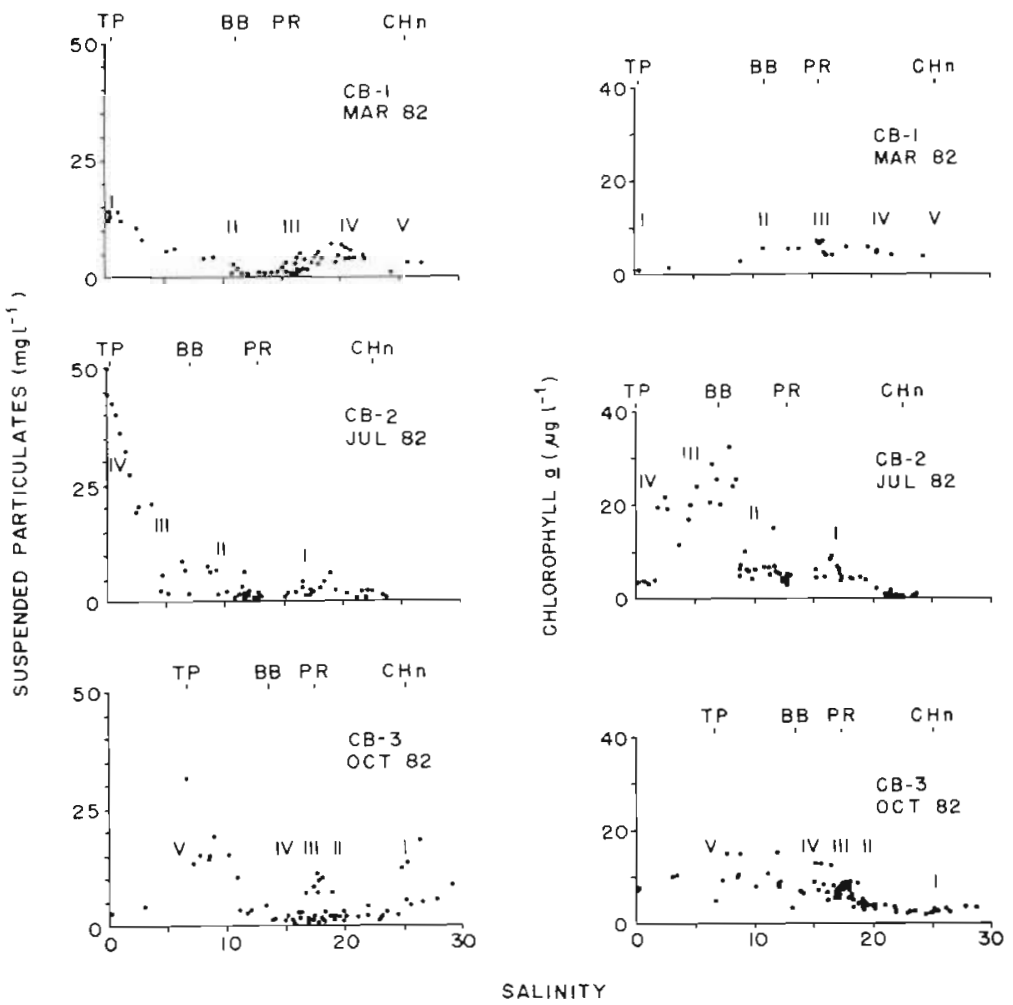

did the other samples. $P_{m}{ }^{B}$ was generally highest for surface samples and those from mid-depth (Table 5), although in early spring (CB-1) such differences between depths were marginal $(0.1<\mathrm{P}<0.5)$.

The response of photosynthesis to short-term exposure to 'low light' was studied by analyzing the P-I relation for phytoplankton collected from the surface mixed layer along the turbidity gradient. Along the estuary's axis, phytoplankton in the surface layer experience different mean light intensities and total light during the day, but the same range of light intensities from darkness to full sunlight. No difference was detected in the relation of $\alpha^{B}$ to $P_{m}{ }^{B}$ for surface samples at stations on an individual cruise, as demonstrated by the consistent, linear relation between $\alpha^{B}$ and $\mathrm{P}_{\mathrm{m}}{ }^{\mathrm{B}}$ (Fig. 6). Rather, the gradient in turbidity and

Table 2. Tidally averaged properties of the stations on the 3 Chesapeake Bay cruises: salinity of the mixed layer (S); light extinction coefficient $\left(\mathrm{k}_{\mathrm{t}}\right)$; depths of the photic zone $\left(\mathrm{Z}_{\mathrm{p}}\right)$, mixed layer $\left(\mathrm{Z}_{\mathrm{m}}\right)$, and water column $(\mathrm{H})$; ambient irradiance $\left(\mathrm{I}_{0}\right)$; mean photic zone light energy $\left(\mathrm{I}_{\mathrm{m}}\right)$

\begin{tabular}{|c|c|c|c|c|c|c|c|c|}
\hline Cruise & Station & $\begin{array}{c}S \\
(\% \circ)\end{array}$ & $\begin{array}{c}\mathrm{k}_{\mathrm{t}} \\
\left(\mathrm{m}^{-1}\right)\end{array}$ & $\begin{array}{l}\mathrm{Z}_{\mathrm{p}} \\
(\mathrm{m})\end{array}$ & $\begin{array}{l}Z_{m} \\
(m)\end{array}$ & $\begin{array}{c}\mathrm{H} \\
(\mathrm{m})\end{array}$ & $\left(E \mathrm{~m}^{-2} \mathrm{~d}^{-1}\right)$ & ${ }_{-1}{ }^{I} Z_{m}$ \\
\hline CB-1 & I & 0 & 1.8 & 2.6 & 6.0 & 6.0 & 28 & 2.6 \\
\hline \multirow{4}{*}{ Маг 82} & II & 11 & 0.77 & 6.0 & 4.0 & 7.5 & 3.1 & .93 \\
\hline & III & 16 & 0.40 & 12 & 5.8 & 12 & 3.3 & 1.6 \\
\hline & IV & 21 & 0.24 & 12 & 12 & 12 & 36 & 12 \\
\hline & V & 25 & 0.15 & 11 & 3.8 & 11 & 33 & 25 \\
\hline CB-2 & I & 17 & 0.57 & 8.1 & 6.0 & 11 & 52 & 15 \\
\hline \multirow[t]{3}{*}{ Jul 82} & II & 10 & 1.0 & 4.6 & 7.6 & 9.0 & 55 & 7.3 \\
\hline & III & 4 & 1.4 & 3.4 & 3.3 & 7.0 & 58 & 13 \\
\hline & IV & 0 & 2.8 & 1.7 & 5.0 & 5.0 & 16 & 1.2 \\
\hline CB-3 & I & 25 & 0.54 & 8.6 & 7.0 & 15 & 19 & 5.0 \\
\hline \multirow[t]{4}{*}{ Oct 82} & II & 19 & 0.49 & 9.5 & 5.0 & 12 & 20 & 7.4 \\
\hline & III & 17 & 0.75 & 6.1 & 11 & 11 & 21 & 2.5 \\
\hline & IV & 15 & 0.98 & 4.7 & 8.0 & 8.0 & 18 & 2.3 \\
\hline & V & 4 & 1.9 & 2.4 & 3.8 & 5.0 & 26 & 3.5 \\
\hline
\end{tabular}


accompanying differences in mean light intensity and total light appeared to be reflected in the absolute magnitudes of $\alpha^{B}$ and $P_{m}{ }^{B}$ values, and not in the ratio of these values. Coordinate pairs $\left(\mathrm{P}_{\mathrm{m}}{ }^{\mathrm{B}}, \alpha^{\mathrm{B}}\right)$ for each station tended to group together along the line, and the 4 or 5 P-I curve measurements made daily represented diel periodicity of the P-I relation (see Harding et al. 1982, 1983).

The response of photosynthesis to long-term exposure to 'low light' was studied by analyzing P-I relations for phytoplankton at different vertical positions in the water column. Phytoplankton from the surface mixed layer and from the pycnocline and below experienced both different mean light intensities and total light per day, as did phytoplankton from the surface layer along the turbidity gradient. But samples collected from depth also experienced different ranges of light intensities. $\alpha^{\mathrm{B}}$ and $\mathrm{P}_{\mathrm{m}}{ }^{\mathrm{B}}$ for phytoplankton from comparable vertical positions at stations on each cruise were, in general, correlated and linearly related (Fig. 6). Seasonal changes in the slopes of lines describing the $\alpha^{B}$ to $P_{m}^{B}$ relation were observed (i.e. between cruises), with higher slopes occurring in early spring (CB-1) for surface ('white'), mid-depth ('blue-green'), and deep ('orange') samples. The slopes declined in the higher irradiance and temperature conditions of summer (CB-2) for surface and deep samples, but remained elevated for samples that were collected from mid-depth (Table 4, Fig. 6). Thus, unlike P-I patterns for phytoplankton from the surface mixed

Table 3. Concentrations of photosynthetic pigments (mean \pm SE) for 3 cruises in Chesapeake Bay, Mar to Oct 1982

\begin{tabular}{|c|c|c|c|c|c|c|c|c|c|}
\hline \multirow{3}{*}{$\begin{array}{l}\text { Cruise } \\
\text { CB-1 }\end{array}$} & \multirow{3}{*}{$\underbrace{}_{\text {Station }}$} & \multirow{3}{*}{$\begin{array}{c}\begin{array}{c}\text { Depth } \\
\text { (m) }\end{array} \\
1\end{array}$} & \multirow{2}{*}{$\begin{array}{c}\text { Chla } \\
\left(\text { nmoles } 1^{-1}\right)\end{array}$} & \multirow{2}{*}{$\begin{array}{c}\text { Chl } b \\
\left(\text { (nmoles l-1 }^{-1}\right)\end{array}$} & \multirow{2}{*}{$\begin{array}{c}\text { Chl } c \\
\left(\text { nmoles } 1^{-1}\right)\end{array}$} & \multirow{2}{*}{$\begin{array}{l}\text { Carotenoids } \\
\left(\text { nSPU } 1^{-1}\right)^{\cdot}\end{array}$} & \multicolumn{3}{|c|}{ Pigment ratios } \\
\hline & & & & & & & $a: b$ & $a: c$ & carot: a \\
\hline & & & $4.4(.72)$ & $2.5 \quad(.28)$ & $5.1 \quad(1.2)$ & $24 \quad$ (nd) & 1.7 & .86 & 5.5 \\
\hline \multirow[t]{10}{*}{ Mar 82} & II & 1 & $9.0(.58)$ & $3.6 \quad(.55)$ & $7.1 \quad(1.3)$ & $22 \quad(2.1)$ & 2.5 & 1.3 & 2.4 \\
\hline & & 3.5 & $9.5(.83)$ & $4.0 \quad(.53)$ & $7.4 \quad(1.1)$ & $24 \quad(1.4)$ & 2.4 & 1.3 & 2.5 \\
\hline & & 5.5 & $8.4(1.3)$ & $3.0 \quad(.66)$ & $6.1 \quad(1.6)$ & $23 \quad(3.6)$ & 2.8 & 1.4 & 2.7 \\
\hline & III & 1 & $3.4(.29)$ & $1.5(.10)$ & $2.8 \quad(.28)$ & $8.5(1.2)$ & 2.2 & 1.2 & 2.5 \\
\hline & & 5 & $4.1(.38)$ & $1.7 \quad(.28)$ & $3.4 \quad(.48)$ & $10 \quad(.98)$ & 2.5 & 1.2 & 2.4 \\
\hline & & 12 & $7.3(1.4)$ & $2.4 \quad(.43)$ & $4.8 \quad(.80)$ & $15 \quad(3.0)$ & 3.0 & 1.5 & 2.1 \\
\hline & IV & 1 & $3.5(.86)$ & $1.4 \quad(.35)$ & $3.0 \quad(.61)$ & $9.5(2.2)$ & 2.4 & 1.2 & 2.7 \\
\hline & V & 1 & $2.9(.54)$ & $.68(.31)$ & $1.2(.52)$ & $6.2(3.4)$ & 4.3 & 2.4 & 2.1 \\
\hline & & 6 & $2.1(.50)$ & $.46(.14)$ & $1.0 \quad(.20)$ & 6.2 (nd) & 4.6 & 2.1 & 3.0 \\
\hline & & 9 & $1.8(.38)$ & $.42(.22)$ & $1.6 \quad(.69)$ & 9.8 (nd) & 4.3 & 1.1 & 5.4 \\
\hline CB-2 & I & 1 & $4.8(.59)$ & $2.4 \quad(.06)$ & $3.9 \quad(.82)$ & $22 \quad(1.3)$ & 2.0 & 1.2 & 4.6 \\
\hline \multirow[t]{9}{*}{ Jul 82} & & 6 & $6.1(.43)$ & $1.8 \quad(.37)$ & $4.3 \quad(.61)$ & $22 \quad(1.9)$ & 3.4 & 1.4 & 3.6 \\
\hline & & 10 & $4.3(.19)$ & $2.0 \quad(.28)$ & $4.1 \quad(.38)$ & $18 \quad(.42)$ & 2.2 & 1.1 & 4.2 \\
\hline & II & 1 & $13 \quad(.90)$ & $3.2(.71)$ & $3.9(.80)$ & $32 \quad(2.6)$ & 4.1 & 3.3 & 2.5 \\
\hline & & 4 & $17 \quad(.75)$ & $2.0 \quad(.51)$ & $5.1 \quad(.49)$ & $30 \quad(8.6)$ & 8.6 & 3.3 & 1.8 \\
\hline & & 8 & $13 \quad(2.4)$ & $2.0(.18)$ & $4.6 \quad(1.0)$ & $24 \quad(6.8)$ & 6.6 & 2.8 & 1.9 \\
\hline & III & 1 & $9.7(.67)$ & $3.4 \quad(.63)$ & $3.4 \quad(.23)$ & 20 & 2.9 & 2.9 & 2.1 \\
\hline & & 5 & $7.4(.52)$ & $2.0 \quad(.52)$ & $2.3 \quad(.69)$ & $17 \quad(1.5)$ & 3.7 & 3.2 & 2.3 \\
\hline & & 7 & $6.3(.34)$ & $2.5 \quad(.45)$ & $2.8 \quad(.57)$ & $19 \quad(.42)$ & 2.5 & 2.3 & 3.0 \\
\hline & IV & 1 & $17 \quad(.88)$ & $1.4 \quad(.46)$ & $2.1 \quad(.51\}$ & $28 \quad(1.1)$ & 12 & 8.1 & 1.7 \\
\hline $\mathrm{CB}-3$ & I & 1 & $4.3(1.2)$ & $.64(.14)$ & $.90(.21)$ & $7.5(1.7)$ & 6.7 & 4.8 & 1.7 \\
\hline \multirow[t]{14}{*}{ Oct 82} & & 5 & $2.9(.30)$ & $.39(.11)$ & $.82(.18)$ & $6.4(.58)$ & 7.5 & 3.5 & 2.2 \\
\hline & & 12 & $3.7(.35)$ & $11(.08)$ & $.90(.16)$ & $9.1(1.2)$ & 34 & 4.1 & 2.5 \\
\hline & II & 1 & $4.7(.21)$ & $17(.17)$ & $.74(.10)$ & $9.6(2.3)$ & 28 & 6.4 & 2.0 \\
\hline & & 6 & $4.3(.59)$ & $.03(.00)$ & $.82(.28)$ & $9.5(2.0)$ & 142 & 5.2 & 2.2 \\
\hline & & 11 & $4.0(.26)$ & $.61(.26)$ & $2.0 \quad(.39)$ & $10 \quad(.78)$ & 6.6 & 2.0 & 2.5 \\
\hline & III & 1 & $8.5(1.1)$ & 0 & $.74(.28)$ & $14 \quad(1.4)$ & $\infty$ & 12 & 1.7 \\
\hline & & 5 & $9.5(.71)$ & 0 & $1.0 \quad(.23)$ & $16 \quad(1.3)$ & $\infty$ & 9.5 & 1.7 \\
\hline & & 9 & $8.4(1.2)$ & 0 & $.33(.20)$ & $15 \quad(2.7)$ & $\infty$ & 25 & 1.8 \\
\hline & IV & 1 & $9.7(3.7)$ & $.06(.06)$ & $1.3 \quad(.38)$ & $20 \quad(4.6)$ & 162 & 7.5 & 2.1 \\
\hline & & 2 & $15 \quad(1.6)$ & 0 & $2.1 \quad(.56)$ & $23 \quad(2.8)$ & $\infty$ & 7.1 & 1.5 \\
\hline & & 7 & $13 \quad(1.7)$ & $.11(.11)$ & $1.8 \quad(.15)$ & $20 \quad(3.2)$ & 117 & 7.2 & 1.5 \\
\hline & V & 1 & $34 \quad(3.9)$ & $4.4 \quad(1.8)$ & $11 \quad(2.5)$ & $53 \quad(5.7)$ & 7.7 & 3.1 & 1.6 \\
\hline & & 2.5 & $25 \quad(8.2)$ & $4.4 \quad(1.5)$ & (3.5) & $48 \quad(5.3)$ & 5.5 & 2.1 & 1.9 \\
\hline & & 5 & $23 \quad(4.0)$ & $5.1 \quad(1.5)$ & $11 \quad(2.7)$ & $25 \quad(8.3)$ & 4.5 & 2.1 & 1.1 \\
\hline
\end{tabular}



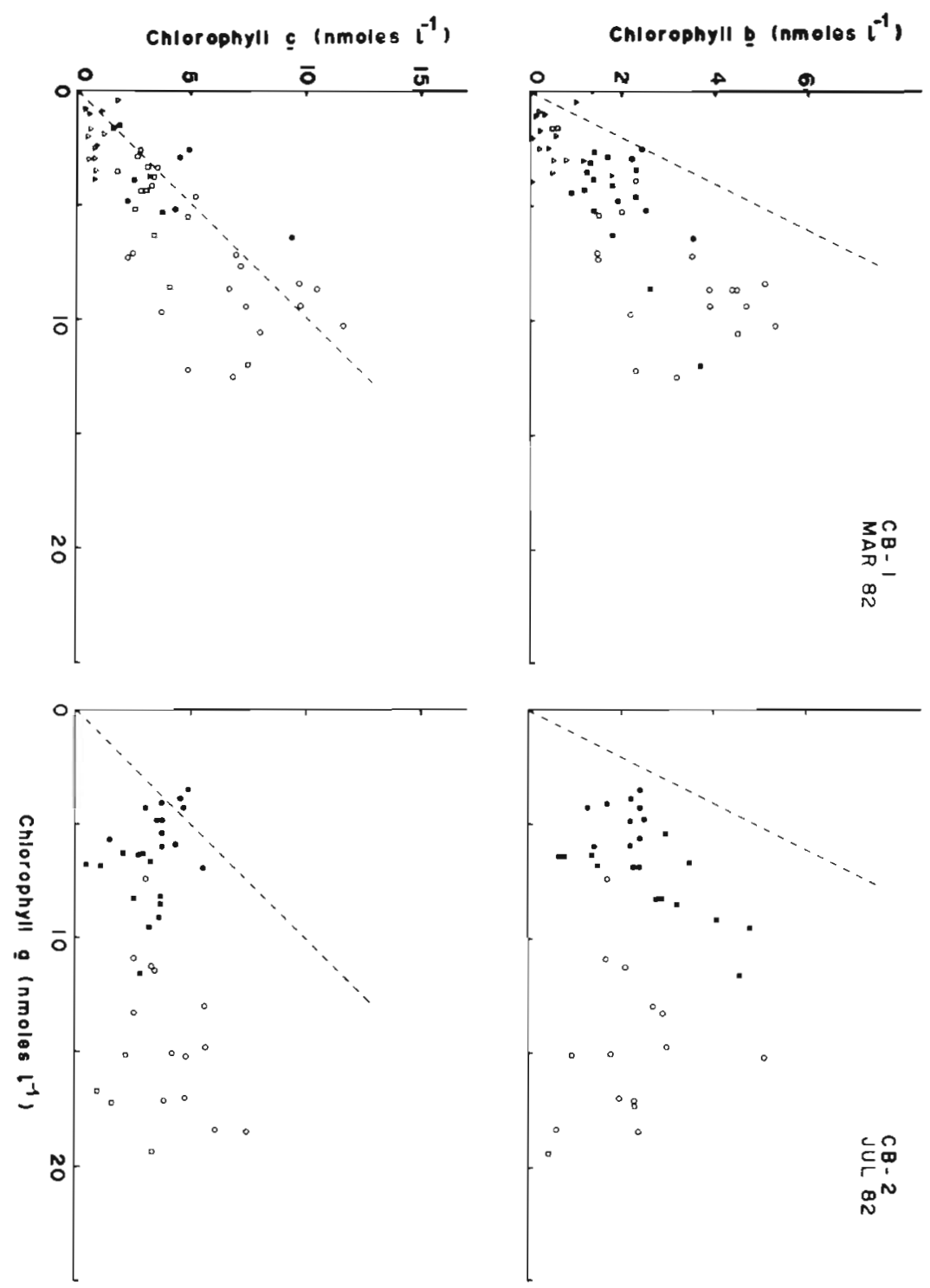

Fig. 5. Molar concentrations of photosynthetic pigments in phytoplankton from Chesapeake Bay cruises. Dashed lines indicate 1:1 molar ratios of pigments. Symbols correspond to samples from distinct stations

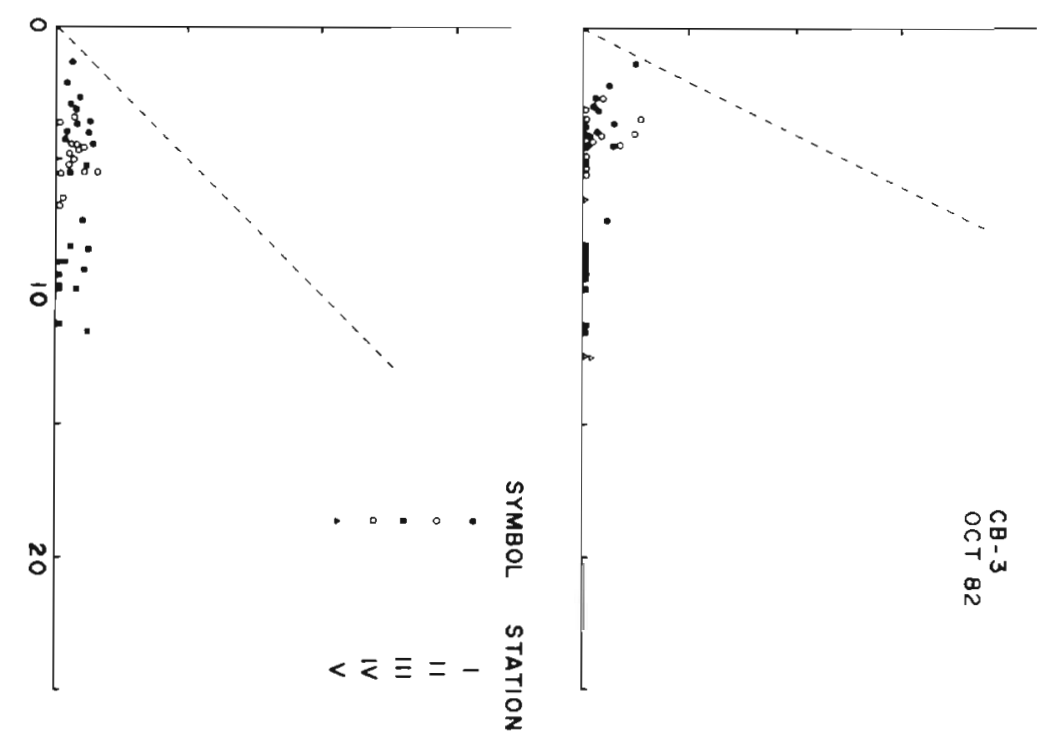


Table 4. Means of $\mathrm{P}-\mathrm{I}$ curve parameters $\alpha^{\mathrm{B}}$ and $\mathrm{P}_{\mathrm{m}}{ }^{\mathrm{B}}( \pm \mathrm{SE})$ and values of the light saturation parameter $\left(\mathrm{I}_{\mathrm{k}}\right)$. Color designations are $\mathrm{W}$ (white), $\mathrm{B}$ (blue), and $\mathrm{O}$ (orange) and correspond to the light quality in simulated in situ incubations

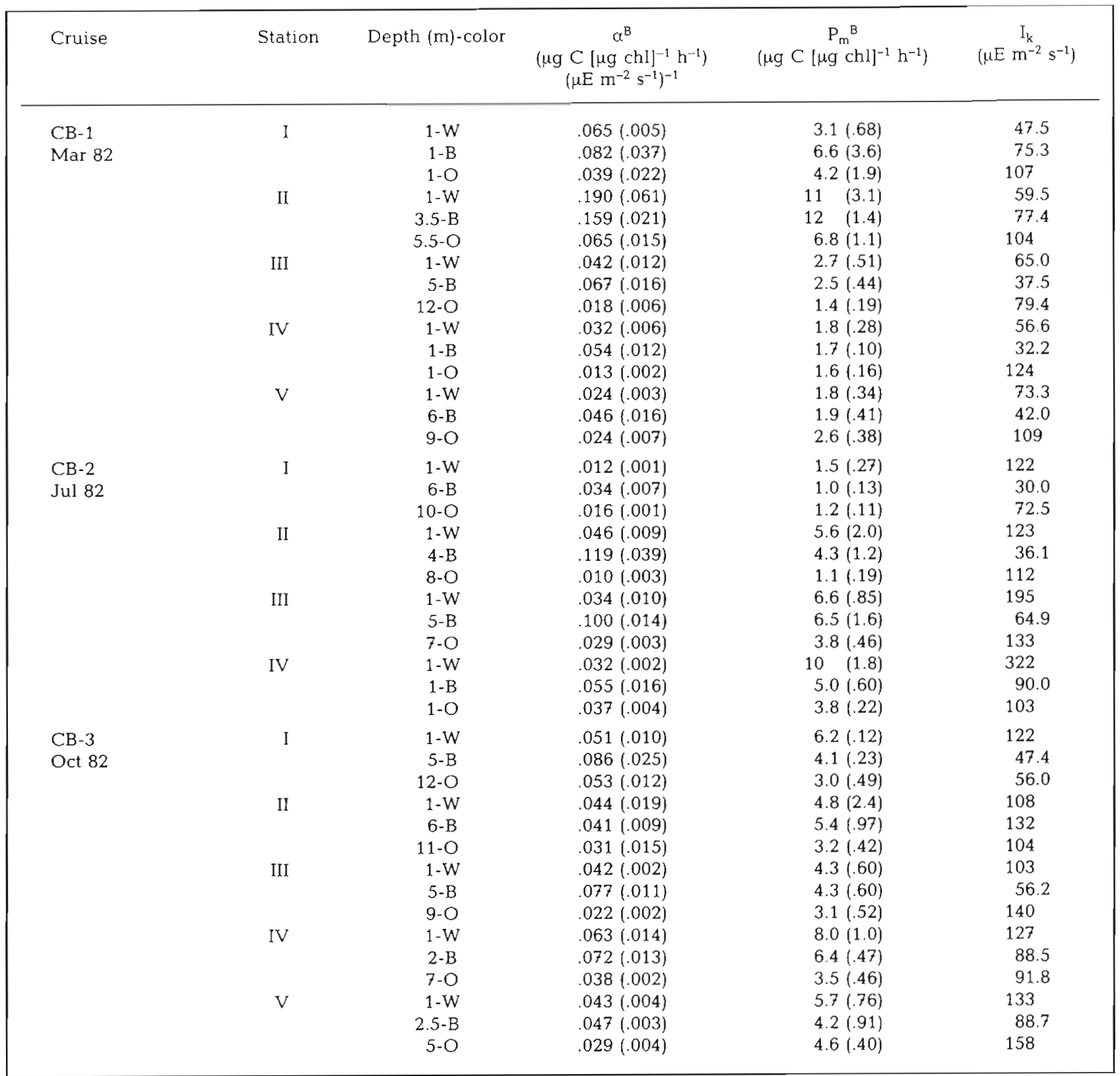

layer along the turbidity gradient, patterns for phytoplankton collected in and below the strong pycnocline did show changes in the ratio of light-limited to lightsaturated photosynthesis. In autumn (CB-3), the correlation of $\alpha^{B}$ and $P_{m}{ }^{B}$ detected in earlier cruises was found for surface samples, with a slope intermediate between that of early spring and summer. P-I curve parameters for phytoplankton from mid-depth or deep were not linearly related in autumn.

Use of 3 distinct light sources in our incubations provided some limited data on chromatic adaptation.
The most apparent influence of light quality on photosynthesis was observed for stratified stations during summer (CB-2). Phytoplankton samples collected from mid-depth and incubated in 'blue-green' light showed a higher photosynthetic efficiency expressed as $\alpha^{B}$ than did samples from the other depths (Table 4 \& 5). For samples collected in the surface mixed layer at wellmixed stations and incubated in each of the 3 light sources, we did not observe differences in P-I curve parameters associated with spectral differences in incubations. 
Table 5. Summary of statistical comparisons of P-I curve parameters for samples from different depths. W, B, and O designations are as described in Table 4 legend. Levels of significance: $>$ indicates $\mathrm{P}<.10 ;>>$ indicates $\mathrm{P}<.05$ for F-test and $\mathrm{t}$-test

\begin{tabular}{|c|c|c|c|}
\hline Cruise & Station (condition) & $\begin{array}{l}\alpha^{B}(2 \text {-Way ANOVA, } \\
\text { no replication) }\end{array}$ & $\begin{array}{l}\mathrm{P}_{\mathrm{m}}^{\mathrm{B}} \text { (Student's t-test, } \\
\text { 2-tailed) }\end{array}$ \\
\hline $\mathrm{CB}-1$ & $\begin{aligned} \text { I } & \text { (mixed) } \\
\text { II } & \text { (stratified) } \\
\text { III } & \text { (stratified) } \\
\text { IV } & \text { (mixed) } \\
V & \text { (stratified) }\end{aligned}$ & $\begin{array}{l}\mathrm{W}=\mathrm{B}=\mathrm{O} \\
\mathrm{W}=\mathrm{B}>> \\
\mathrm{W}=\mathrm{B}=\mathrm{O} \\
\mathrm{W}=\mathrm{B}=\mathrm{O} \\
\mathrm{W}=\mathrm{B}=\mathrm{O}\end{array}$ & $\begin{array}{l}\mathrm{W}=\mathrm{B}=\mathrm{O} \\
\mathrm{W}=\mathrm{B}, \mathrm{W}=\mathrm{O}, \mathrm{B}>\mathrm{O} \\
\mathrm{W}=\mathrm{B}, \mathrm{W}>\mathrm{O}, \mathrm{B}>\mathrm{O} \\
\mathrm{W}=\mathrm{B}=\mathrm{O} \\
\mathrm{W}=\mathrm{B}=\mathrm{O}\end{array}$ \\
\hline $\mathrm{CB}-2$ & $\begin{aligned} \text { I } & \text { (stratified) } \\
\text { II } & \text { (stratified) } \\
\text { III } & \text { (stratified) } \\
\text { IV } & \text { (mixed) }\end{aligned}$ & $\begin{array}{l}B>P=O \\
B>>W=O \\
B>>W=O \\
W=B=0\end{array}$ & $\begin{array}{l}W=B=O \\
W=B, W>O, B>>O \\
W=B, W>>, B=O \\
W>>B, W>>O, B=O\end{array}$ \\
\hline $\mathrm{CB}-3$ & $\begin{aligned} \text { I } & \text { (stratified) } \\
\text { II } & \text { (stratified) } \\
\text { III } & \text { (stratified) } \\
\text { IV } & \text { (stratified) } \\
\text { V } & \text { (stratified) }\end{aligned}$ & $\begin{array}{l}\mathrm{W}=\mathrm{B}=0 \\
\mathrm{~W}=\mathrm{B}=\mathrm{O} \\
\mathrm{W}=\mathrm{B}>>0 \\
\mathrm{~W}=\mathrm{B}=\mathrm{O} \\
\mathrm{W}=\mathrm{B}>>0\end{array}$ & $\begin{array}{l}\mathrm{W}>>\mathrm{B}, \mathrm{W}>>\mathrm{O}, \mathrm{B}>\mathrm{O} \\
\mathrm{W}=\mathrm{B}=\mathrm{O} \\
\mathrm{W}=\mathrm{B}=\mathrm{O} \\
\mathrm{W}=\mathrm{B}, \mathrm{W}>\mathrm{O}, \mathrm{B}>>0 \\
\mathrm{~W}=\mathrm{B}=\mathrm{O}\end{array}$ \\
\hline
\end{tabular}

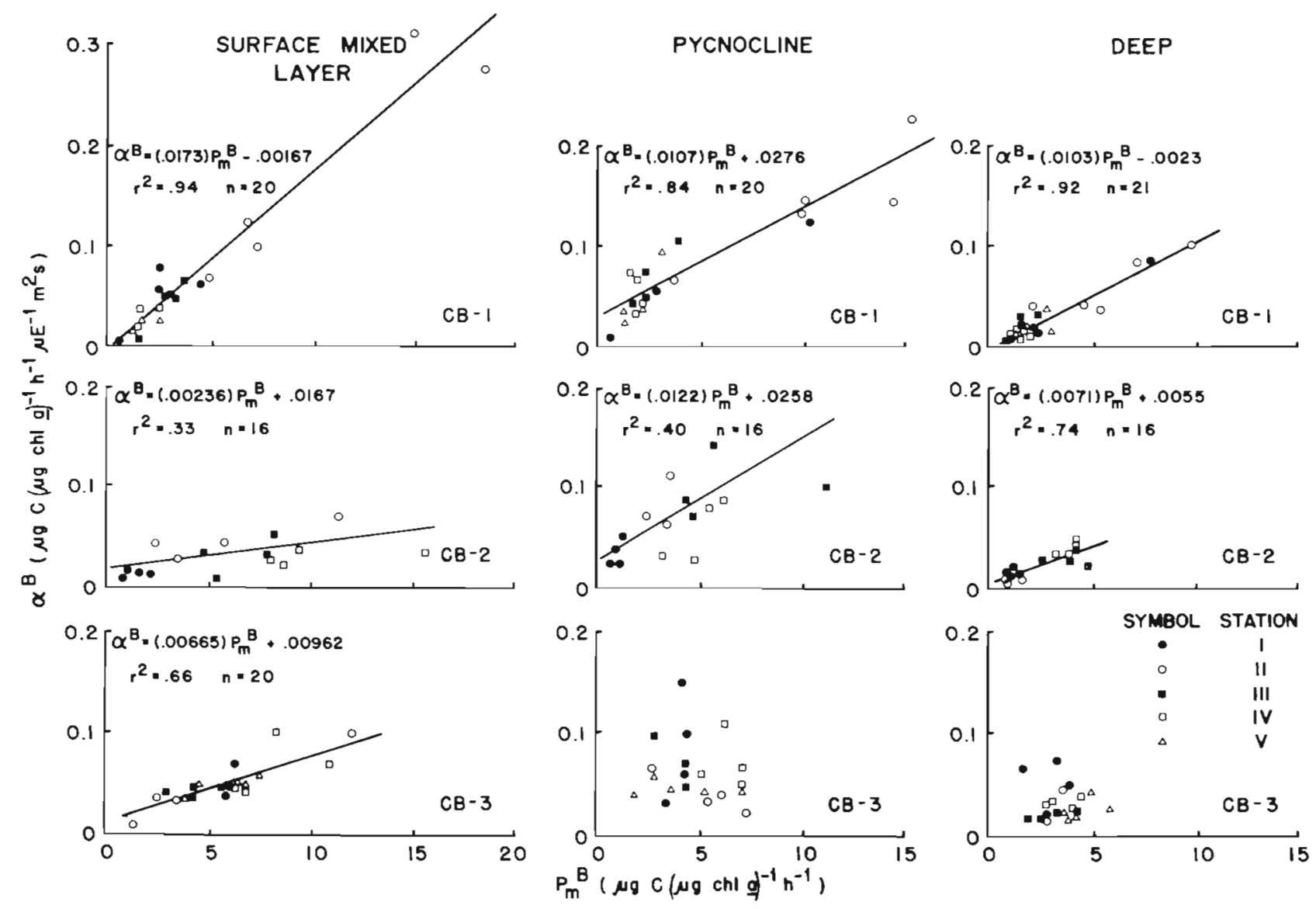

Fig. 6. Plots of $\alpha^{B}$ vs $\mathrm{P}_{\mathrm{m}}^{\mathrm{B}}$ for Chesapeake Bay phytoplankton. P-I curves used to generate these data were determined in simulated in situ light conditions for samples collected at the vertical positions indicated. 'White' light was provided to samples from the surface layer, 'blue-green' light to samples from at or below the pycnocline, and 'orange' light to the deepest samples. Equations describe least-square fits; correlation coefficients $\left(r^{2}\right)$ and sample sizes (n) are given. Symbols correspond to samples 


\section{DISCUSSION}

A correlation between $\alpha^{B}$ and $\mathrm{P}_{\mathrm{m}}{ }^{\mathrm{B}}$ has been observed before for laboratory cultures (Harding et al. 1981a, b, $1983,1984)$, and natural assemblages of phytoplankton (MacCaull \& Platt 1977. Harding et al. 1982, unpubl.). For example, it is known that $a^{\mathrm{B}}$ and $\mathrm{P}_{\mathrm{m}}{ }^{\mathrm{B}}$ remain highly correlated in the dinoflagellate, Prorocentrum mariaelebouriae, during photoadaptive responses to shortterm (i.e. several day) exposures to 'low light' (Harding et al. 1983). The distribution of $\alpha^{B}$ and $P_{m}{ }^{B}$ coordinate pairs shifted along a line describing the correlation when light conditions changed, and the range of values in a day corresponded to the amplitude of diel periodicity in photosynthesis. It is also known that seasonal changes in the relation of $\alpha^{B}$ to $P_{m}{ }^{B}$, whether quantified by $I_{k}$ that equals $P_{m}{ }^{B} / \alpha^{B}$, or by the slope of $\alpha^{B}$ vs $\mathrm{P}_{\mathrm{m}}{ }^{\mathrm{B}}$, may occur in response to changed photoperiod, insolation, temperature, and species composition (cf. Cöté \& Platt 1983, Harding et al. unpubl.).

The data presented here for phytoplankton in Chesapeake Bay show both of these patterns, and demonstrate some interesting aspects of light adaptation in natural phytoplankton assemblages. P-I curve parameters were highly correlated on any 1 cruise, and thereby in a given season, provided that the source of samples (i.e. depth relative to the pycnocline or compensation depth) was comparable. Between cruises or seasons, changes in slope of the correlation were observed. For phytoplankton collected below the pycnocline or near the base of the photic zone, differences were observed in the ratio of $\alpha^{B}$ to $\mathrm{P}_{\mathrm{m}}{ }^{\mathrm{B}}$ as compared to the ratio for surface samples. Phytoplankton in these samples appear to have occupied a relatively stable 'low light' environment below the pycnocline for days to weeks, and the pattern of their P-I curve parameters apparently reflected long-term adaptation to reduced light. Notably, the timing of cruise CB-2 was coincident with the seasonal occurrence of large-scale, subpycnocline transport of dinoflagellates and diatoms northward in the estuary (Tyler \& Seliger 1978, 1981). In some species, this transport is lengthy and cells entrained in that layer experience 'low light' for days to weeks. Persistence of a steep slope for $\alpha^{B} v s P_{m}^{B}$ in summer for samples from mid-depth probably reflects the relative stability of that 'low light' exposure and a disproportionate influence on $\alpha^{B}$ and $P_{m}{ }^{B}$

Shifts in the relation of $\alpha^{B}$ to $P_{m}{ }^{B}$ that occurred seasonally and vertically did not occur along the horizontal gradient of turbidity in the estuary on any single cruise. As already discussed, distributions of $\alpha^{B}$ and $\mathrm{P}_{\mathrm{m}}{ }^{\mathrm{B}}$ provided valid indicators of short-term photoadaptive responses of Prorocentrum mariae-lebouriae in laboratory experiments, but the ratio of the lightlimited slope, $\alpha^{B}$, to the light-saturated rate of photo- synthesis, $\mathrm{P}_{\mathrm{m}}{ }^{\mathrm{B}}$, did not. In contrast, earlier research with other dinoflagellate species (e.g. Gonyaulax polyedra, Glenodinium sp.) documented the responsiveness of this ratio and of derived light-saturation parameters $\left(I_{k}, I_{5}\right)$ to long-term (stable) changes in the photic environment (Prezelin \& Sweeney 1978, Prezelin \& Matlick 1980, Prezelin 1981).

Together, these results suggest that the relation of $\alpha^{B}$ to $\mathrm{P}_{\mathrm{m}}{ }^{\mathrm{B}}$, and parameters derived from that relation, may be poor measures of photoadaptation to short-term changes in light, but that these properties respond to long-term changes in light and reflect physiological trends associated with seasonal influences or relatively stable light conditions. Clearly, seasonal changes in the relation of $\alpha^{B}$ to $P_{m}^{B}$ could also have been associated, in part, with gradients in temperature or species composition, rather than with light conditions alone. Based on data for pigment ratios, for instance, differences in species composition with depth, location, and season occurred during our study, and these may have influenced the slope of $\alpha^{\mathrm{B}}$ vs $\mathrm{P}_{\mathrm{m}}^{\mathrm{B}}$. However, the consistency of our findings using natural assemblages of phytoplankton with results of laboratory studies suggests light as the single most important variable producing the P-I curve patterns we observed.

The several patterns that emerged from our data suggest a link between duration of exposure to 'low light' and adaptive shifts observed in $\alpha^{B}$ and $P_{m}^{B}$. These patterns are summarized in Fig. 7. First, diel periodicity produced synchronous changes in $\alpha^{B}$ and $\mathrm{P}_{\mathrm{m}}{ }^{\mathrm{B}}$ for phytoplankton from a given station, such that the ratio of $\alpha^{B}$ to $P_{m}{ }^{B}$ remained constant during the day (Fig. 7: A). This is consistent with a large body of data on periodicity of photosynthesis (cf. Prezelin et al. 1977, Harding et al. 1981a, 1982, 1983). Second, phytoplankton collected at different stations along the estuarine turbidity gradient on a single cruise showed distinct groupings of $\alpha^{\mathrm{B}}$ and $\mathrm{P}_{\mathrm{m}}^{\mathrm{B}}$ coordinate pairs, with the range of values for each station corresponding to periodicity of photosynthesis. Different ranges of $\alpha^{B}$ and $\mathrm{P}_{\mathrm{m}}{ }^{\mathrm{B}}$ values occurred for phytoplankton from stations along the turbidity gradient, but the relation of $\alpha^{B}$ to $\mathrm{P}_{\mathrm{m}}{ }^{\mathrm{B}}$ remained constant (Fig. $7: \mathrm{A} \rightarrow \mathrm{B}$ ). This response is comparable to that elicited by short-term light shifts in laboratory studies wherein distributions of $\alpha^{B}$ and $\mathrm{P}_{\mathrm{II}}{ }^{\mathrm{B}}$ coordinate pairs responded to a reduction in light, but the relation of $\alpha^{B}$ to $P_{m}{ }^{B}$ was unchanged (Harding et al. 1983). Third, phytoplankton from the pycnocline and below showed grouping of $\alpha^{B}$ and $\mathrm{P}_{\mathrm{m}}{ }^{\mathrm{B}}$ coordinate pairs indicating periodicity, but the ratio of $a^{B}$ to $P_{m}{ }^{B}$ differed from that of phytoplankton in the surface mixed layer (Fig. 7: $\mathrm{A} \rightarrow \mathrm{C}$ ). This response appears to reflect a response to relatively long-term exposure to 'low light' below the density discontinuity, and is consisent with results of photoadaptation studies using 
Fig. 7. Summary of responses of the P-I curve parameters, $\alpha^{B}$ and $P_{m}{ }^{B}$, to different time-scales of change in light conditions

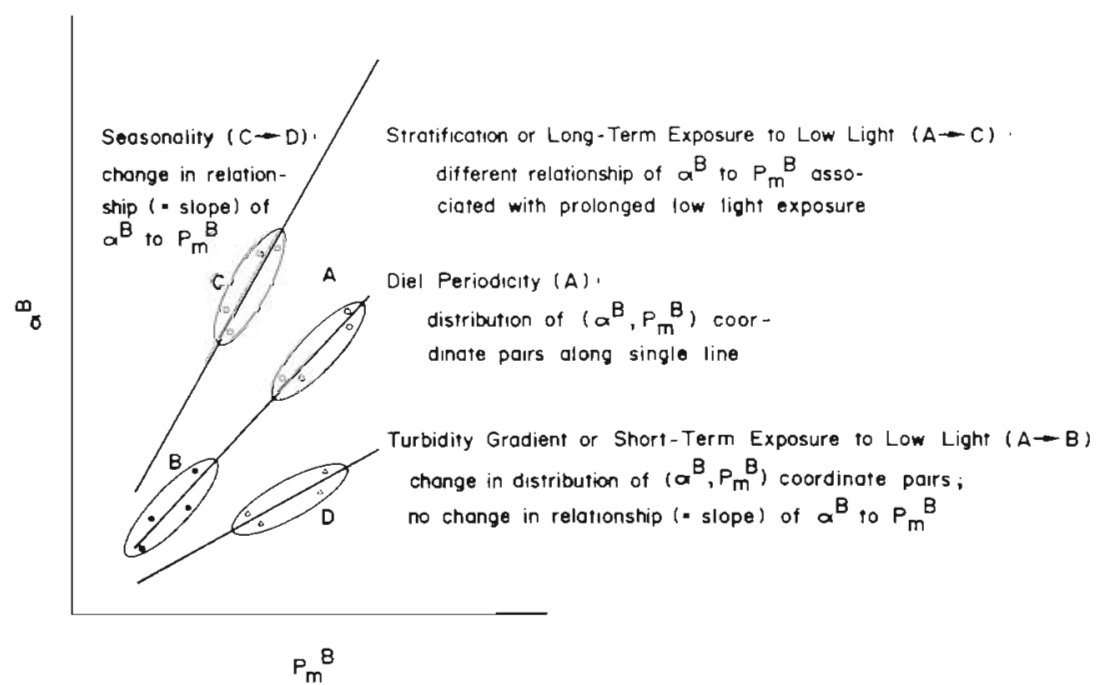

laboratory cultures grown for long periods in stable light conditions at fixed intensities (cf. Prezelin \& Sweeney 1978, Prezelin \& Matlick 1980). Fourth, seasonal changes in the relation of $\alpha^{B}$ to $\mathrm{P}_{\mathrm{m}}{ }^{\mathrm{B}}$ were observed in samples from the surface mixed layer (Fig. 7: C $\rightarrow$ D), a finding that is consistent with the disproportionate seasonal changes in these parameters reported by Cöté \& Platt (1983). Together, this group of responses may serve as a framework for further studies of how P-I curves respond to different time-scales of change in light conditions.

Ratios of chlorophylls $a, b$, and $c$ are easily obtained and can be useful indicators of the occurrence and distribution of major phytoplankton taxa. For example, low molar ratios of chl $a: b(\rightarrow 1)$ indicate a relative abundance of chlorophytes and euglenoids, as these are among the few taxa containing this pigment combination (Scagel et al. 1965). Data in Table 3 show that these taxa were present during the spring and summer (CB-1 and 2). The highest chl $b$ concentration and lowest molar ratios of chl $a: b$ generally occurred near the freshwater end of the estuary (CB-1, Sta. I; CB-3, Sta. V). In contrast, low molar ratios of chl $a: b$ coincided with a relative abundance of dinoflagellates, diatoms and chrysophytes, very prominent components of the marine and estuarine flora. Organisms with this pigment composition also occurred during spring (CB1) and summer (CB-2). The occurrence of chl $a$ in the near absence of chl $b$ and/or chl $c$ (i.e. ratios of chl $a: b$ and $a: c \rightarrow \infty)$ indicates the presence of cyanobacteria (blue-green algae), the major floral component in phytoplankton that lacks one of the other accessory chlorophyll pigments. This situation occurred in autumn (CB-3) under conditions of low runoff and low nutrients (Fisher et al. unpubl.), suggesting the predominance of cyanobacteria. Predominance of cyanobacteria in Chesapeake Bay could be associated with anthropogenic nutrient inputs and is suggestive of eutrophication. There did not appear to be large variations in pigment ratios with depth at most stations, although the concentrations of pigments did show some vertical differences (Table 3). Clearly, pigment ratios cannot replace direct counts and enumeration of species as means of describing phytoplankton species composition. As applied here, though, these ratios can provide useful information on seasonal and spatial trends in phytoplankton distributions for some major taxa that are distinguished, in part, by specific combinations of the chlorophyllous pigments.

The rationale for using 3 distinct light spectra in this study was to simulate in situ conditions and not to examine chromatic adaptation in detail. Several findings that emerged, however, are possibly associated with that phenomenon. Chromatic adaptation yields increased photosynthetic efficiency in conjunction with complementary pigment changes (Bogorad 1975 , de Marsac 1977, Dring 1981a, b, Kohl \& Niklisch 1981, Spence 1981, Ramus 1983, Meeson \& Faust 1985). This type of response was observed only at stratified stations in samples from the pycnocline exposed to 'bluegreen' light. It cannot be genuinely termed chromatic adaptation, however, as we did not test phytoplankton from that sampling depth in all 3 light sources. A similar response was detected before for some subpycnocline organisms containing chl $a$ and $c$ in Chesapeake Bay (Meeson et al. unpubl.); P-I curve parameters for phytoplankton exposed to 'orange' light, similar in spectral distribution to that used in the present study, were as high as those for the same phytoplankton incubated in sunlight. That finding and results described in this paper for natural phytoplankton assemblages in the Chesapeake demonstrate the effective use of a narrow spectral distribution by subsurface phytoplankton at equivalent or greater 
efficiencies as surface phytoplankton used 'white' light. The diversity of photosynthetic pigments present in phytoplankton from the estuary may have contributed to chromatic responses to ambient light conditions, and, in turn, promoted efficient photosynthesis in light of the narrowed in situ spectrum. That we did not observe a significant difference in the efficiency of light utilization for single samples collected from the surface mixed layer and incubated in each of the light sources suggests that photosynthetic pigments present in the resident phytoplankton compensated for narrowed in situ spectral regimes by effectively absorbing light of those wavelength bands.

\section{SUMMARY}

The light response of photosynthesis was studied for phytoplankton assemblages in Chesapeake Bay using P-I curve parameters measured in simulated in situ photic conditions. Short-term (minutes to hours) responses were studied in phytoplankton collected from the surface mixed layer along a horizontal gradient in turbidity. A high correlation of the lightlimited slope, $\alpha^{\mathrm{B}}$, with the light-saturated asymptote, $\mathrm{P}_{\mathrm{m}}{ }^{\mathrm{B}}$, occurred on each cruise in March, July, and October. The distributions of $\alpha^{B}$ and $P_{m}{ }^{B}$ coordinate pairs, rather than the ratio of the parameters, showed between-station differences. Long-term responses (days to weeks) were studied with phytoplankton samples spaced vertically in relation to the pycnocline. P-I curve parameters were linearly related in most cases, but the slope of the correlation and the relation (i.e. ratio) of $\alpha^{B}$ to $P_{m}{ }^{B}$ differed for phytoplankton collected at distinct positions in the water column. These results suggest that photoadaptive responses manifested as changes in P-I functions are specific to the time-scale of exposure to low light.

Acknowledgements. We thank D. Fisher, M. Mallonee, K. Morrissey, J. Sager, D. Stanley, and the captain and crew of the R/V Cape Hatteras for their contributions to the success of this work. Research support was provided by NSF Grants OCE 82-03962 (TRF) and OCE 83-10407 (LWH), and NOAA (Univ. Maryland Sea Grant College) Grant NA84AA-D-00014 (LWH).

\section{LITERATURE CITED}

Baatz, I. (1941). Die Bedeutung der Lichtqualität für Wachstum und Stoffproduktion planktontischer Meeres-diatomeen. Planta 31: 726-768

Bard, Y. (1974). Nonlinear parameter estimation. Academic Press, New York

Bogorad, L. (1975). Phycobiliproteins and complementary chromatic adaptation. A. Rev. Pl. Physiol. 26: 369-401

Champ, M. A., Gould, G. A., Bozzo, W. A., Ackleson, S. G., Vierra, K. C. (1980). Characterization of light extinction and attenuation in Chesapeake Bay, August, 1977. In:
Kennedy, V. S. (ed.) Estuarine perspectives. Academic Press, New York, p. 262-277

Cöté, B., Platt, T. (1983). Day-to-day variations in the springsummer photosynthetic parameters of coastal marine phytoplankton. Limnol. Oceanogr. 28: 320-344

de Marsac, N. T. (1977). Occurrence and nature of chromatic adaptation in cyanobacteria. J. Bacteriol. 30: 82-91

Dring, M. J. (1981a). Photosynthesis and development of marine macrophytes in natural light spectra. In: Smith, H. (ed.) Plants and the daylight spectrum. Academic Press, London, p. 297-314

Dring, M. J. (1981b). Chromatic adaptation of photosynthesis in benthic marine algae: an examination of its ecological significance using a theoretical model. Limnol. Oceanogr 26: $271-284$

Falkowski, P. G. (1980). Light-shade adaptation in marine phytoplankton. In: Falkowski, P. G. (ed.) Primary productivity in the sea. Plenum Press, New York, p. 99-121

Gabrielsen, E. K., Steemann Nielsen, E. (1938). Kohlensäureassimilation und Lichtqualität bei den marinen Planktondiatomeen. Rapp. P.-v. Réun. Cons. Perm. int. Explor. Mer 108: 19-21

Gallegos, C. L, Platt, T. (1981). Photosynthesis measurements on natural populations of phytoplankton: numerical analysis. In: Platt, T. (ed.) Physiological bases of phytoplankton ecology. Can. Bull. Fish. Aquat. Sci. 210: 103-112

Harding, L. W., Jr., Heinbokel, J. F. (1984). Periodicities of photosynthesis and cell division: behavior of phase-lagged replicate cultures of Ditylum brightwellii in a diurnally varying photic regime. Mar. Ecol. Prog. Ser. 15: 225-232

Harding, L. W., Jr, Meeson, B. W., Prézelin, B. B., Sweeney, B. M. (1981a). Diel periodicity of photosynthesis in marine phytoplankton. Mar. Biol. 61: 95-105

Harding, L. W., Jr., Meeson, B. W., Tyler, M. A. (1983). Photoadaptation and diel periodicity of photosynthesis in the dinoflagellate Prorocentrum mariae-lebouriae. Mar. Ecol. Prog. Ser. 13: 73-85

Harding, L. W., Jr., Prézelin, B. B., Sweeney, B. M., Cox, J. L. (1981b). Diel oscillations in the photosynthesis-irradiance relationship of a planktonic marine diatom. J. Phycol. 17: 389-394

Harding, L. W., Jr., Prézelin, B. B., Sweeney, B. M., Cox, J. L. (1982). Diel oscillations of the photosynthesis-irradiance (P-I) relationship in natural assemblages of phytoplankton. Mar. Biol. 67: 167-178

Jassby, A. D., Platt, T. (1976). Mathematical formulation of the relationship between photosynthesis and light for phytoplankton. Limnol. Oceanogr. 21: 540-547

Jeffrey, S. W. (1968). Quantitative thin-layer chromatography of chlorophylls and carotenoids from marine algae. Biochim. biophys. Acta 162: 271-285

Jeffrey, S. W. (1980). Algal pigment systems. In: Falkowski, P. G. (ed.) Primary productivity in the sea. Plenum Press, New York, p. 33-58

Jeffrey, S. W. (1981). An improved thin-layer chromatographic technique for marine phytoplankton pigments. Limnol. Oceanogr. 26: 191-197

Jeffrey, S. W., Humphrey, G. F. (1975). New spectrophotometric equations for determining chl $a, b, c_{1}$ and $c_{2}$ in higher plants, algae and natural phytoplankton. Biochem. Physiol. Pflanz. 167: 191-194

Jeffrey, S. W., Vesk, M. (1977). Effect of blue-green light on photosynthetic pigments and chloroplast structure in the marine diatom Stephanopyxis turris. J. Phycol. 13: $271-279$ 
Jerlov, N. G. (1976). Marine optics. Elsevier, Amsterdam

Kirk, J. T O. (1976). Yellow substance (Gelbstoff) and its contribution to the attenuation of photosynthetically active radiation in some inland and coastal southeastern Australian waters. Aust. J. mar. Freshwat. Res. 27: 61-71

Kirk, J. T. O. (1979). Spectral distribution of photosynthetically active radiation in some southeastern Australian waters. Aust. J. mar. Freshwat. Res. 30: 81-91

Kirk, J. T. O. (1983). Light and photosynthesis in aquatic ecosystems. Cambridge Univ. Press, Cambridge

Kohl, J. G., Niklisch. A. (1981). Chromatic adaptation of the planktonic blue-green alga Oscillatoria redekei van Goor and its ecological significance. Int. Revue ges. Hydrobiol. 66: $83-94$

Larkum, A. W. D., Barrett, J. (1983). Light-harvesting processes in algae. Adv. bot. Res. 10: 1-219

MacCaull, W. A., Platt, T. (1977). Diel variations in the photosynthetic parameters of coastal marine phytoplankton. Limnol. Oceanogr. 22: 723-731

Meeson, B. W., Faust, M. A. (1985). Response of Prorocentrum minimum (Pav.) Schiller (Dinophyceae) to different spectral qualities and irradiances: growth and photosynthesis. In: Gray, J. S., Christianson, M. E. (ed.) 18th European Mar. Biol. Symp. John Wiley and Sons, Chichester (in press)

Platt, T., Gallegos, C. L., Harrison, W. G. (1980). Photoinhibition of photosynthesis in natural assemblages of marine phytoplankton. J. mar. Res. 38: 687-701

Prézelin, B. B. (1981). Light reactions in photosynthesis. In: Platt, T. (ed.) Physiological bases of phytoplankton ecology. Can. Bull. Fish. Aquat. Sci. 210: 1-43

Prézelin, B. B., Matlick, H. A. (1980). Time-course of photoadaptation in the photosynthesis-irradiance relationship of a dinoflagellate exhibiting photosynthetic periodicity. Mar. Biol. 58: 85-96

Prézelin, B. B., Sweeney, B. M. (1978). Photoadaptation of photosynthesis in Gonyaulax polyedra. Mar. Biol. 48: $27-35$

Prézelin, B. B., Meeson, B. W., Sweeney, B. M. (1977). Characterization of photosynthetic rhythms in marine dinoflagel- lates. I. Pigmentation, photosynthetic capacity and respiration. Pl. Physiol., Lancaster 60: 384-387

Qasim, S. Z., Bhattahiri, R., Devassy, M. (1972). The effect of intensity and quality of illumination on the photosynthesis of some tropical marine phytoplankton. Mar. Biol. 16: $22-31$

Ramus, J. (1983). A physiological test of the theory of complementary chromatic adaptation. II. Brown, green and red seaweeds. J. Phycol. 19: 173-178

Scagel, R. F., Rouse, G. E., Stein, J. R., Bandoni, R. J., Schofield, W. B., Taylor, T. M. C. (1965). An evolutionary survey of the plant kingdom. Wadsworth Publ. Co., Belmont, California

Seliger, H. H., McKinley, K. R., Biggley, W. H., Rivkin, R. B., Aspden, K. R. H. (1981). Phytoplankton patchiness and frontal regions. Mar. Biol. 61: 119-131

Spence, D. H. N. (1981). Light quality and plant responses underwater. In: Smith, H. (ed.) Plants and the daylight spectrum. Academic Press, London

Strickland, J. D. H., Parsons, T. R. (1972). A practical handbook of seawater analysis, 2nd ed. Bull. Fish. Res. Bd Can. 167: $1-310$

Tyler, M. A., Seliger, H. H. (1978). Annual subsurface transport of a red tide dinoflagellate to its bloom area: water circulation patterns and organism distributions in the Chesapeake Bay. Limnol. Oceanogr. 23: 227-246

Tyler, M. A., Seliger, H. H. (1981). Selection for a red tide organism: physiological responses to the physical environment. Limnol. Oceanogr. 26: 310-324

Vesk, M., Jeffrey, S. W. (1977). Effect of blue-green light on photosynthetic pigments and chloroplast structure in unicellular marine algae from six classes. J. Phycol. 13: 280-288

Wallen, D. G., Geen, G. H. (1971a). Light quality and concentration of proteins, RNA, DNA and photosynthetic pigments in two species of marine plankton algae. Mar. Biol. 10: $44-51$

Wallen, D. G., Geen, G. H. (1971b). The nature of the photosynthate in natural phytoplankton populations in relation to light quality. Mar. Biol. 10: 157-168 